\title{
APLIKASI TEKNOLOGI SHELTER TERHADAP RESPON STRESS DAN KELANGSUNGAN HIDUP PADA PENDEDERAN LOBSTER PASIR Panulirus homarus
}

\author{
APPLICATION OF VARIOUS SHELTER ON STRESS RESPONSE AND SURVIVAL RATE OF \\ SPINY LOBSTER Panulirus homarus NURSERY
}

\author{
Kukuh Adiyana ${ }^{1}$, Eddy Supriyono², Muhammad Zairin Junior ${ }^{2}$ dan Lolita Thesiana ${ }^{1}$ \\ ${ }^{1}$ Pusat Pengkajian Perekayasaan Teknologi Kelautan Perikanan-Balitbang KP-KKP, \\ Jl Pasir Putih I Ancol, Jakarta, Indonesia \\ ${ }^{2}$ Departemen Budidaya Perairan Fakultas Perikanan dan Ilmu Kelautan IPB \\ E-mail: k_adiyana@yahoo.com
}

Diterima tanggal: 16 Januari 2014, diterima setelah perbaikan: 7 Maret 2014, disetujui tanggal: 14 Maret 2014

\begin{abstract}
ABSTRAK
Penggunaan shelter pada pendederan lobster Panulirus homarus dimaksudkan untuk menekan terjadinya stress dan menghasilkan tingkat kelangsungan hidup yang lebih tinggi. Penelitian ini bertujuan untuk menganalisis dan menentukan jenis shelter yang memberikan respon stress dan produktifitas benih lobster yang paling baik. Pada Penelitian ini digunakan empat perlakuan, perlakuan menggunakan shelter jaring, paralon, lubang angin dan kontrol (tanpa shelter). Penelitian menunjukkan, perlakuan menggunakan shelter paralon merupakan yang terbaik karena terbukti mampu untuk menurunkan tingkat stress dan menghasilkan kelangsungan hidup yang lebih baik. Level Total Hemocycte Count (THC) dan glukosa pada sheltter paralon selama penelitian, menghasilkan respon stress yang lebih rendah dan stabil apabila dibanding dengan perlakuan lainnya.Tingkat kelangsungan hidup pada shelter paralon berbeda nyata $(\mathrm{p}<0,05)$ dengan shelter jaring dan kontrol, tetapi tidak berbeda nyata $(\mathrm{p}>0,05)$ dengan shelter lubang angin.
\end{abstract}

Kata kunci: shelter, lobster, THC, glukosa, kelangsungan hidup

\section{ABSTRACT}

Use of shelters in the nursery of lobster Panulirus homarus intended to suppress the occurrence of stress and result in higher survival rate. This study aims to determine and to find out the best type of shelter in terms of stress response and survival rate. The research was conducted using four treatments. Treatment using shelters from nets, polyvinyl chloride $(P V C)$ pipe, vent and without shelter as a control. Research has shown that treatment using PVC pipe shelter is the best because it proved able to reduce the stress level and shows higher survival rate among another treatment. THC level sand glucose in lobster blood who lived in PVC pipe shelter treatment during the study, resulting lower stress response and stable when compared with other treatments. The survival rate at PVC pipe shelter significantly different ( $p<0.05)$ with net shelter and control, but not significantly different $(p>0.05)$ with vent shelter.

Keywords: shelter, lobster, THC, glucose, survival rate

\section{PENDAHULUAN}

Permintaan kebutuhan lobster air laut di pasar internasional mencapai 2000 - 2500 metric ton/ tahun, sementara pasokan lobster di pasar, tidak tersedia secara kontinyu (Drengstig \& Bergheim, 2013). Hal ini disebabkan oleh daya dukung lobster yang semakin menurun di alam dan pengaruh musim, yang menyulitkan untuk kegiatan penangkapan lobster di alam. Beberapa upaya budidaya lobster Homarus americanus secara intensif telah dilakukan di beberapa negara seperti di Amerika dan Kanada sejak tahun 1970an untuk mengatasi masalah tersebut. Beberapa penelitian mengenai teknik budidaya larva lobster Panulirus ornatus untuk tujuan pembesaran secara komersial juga telah banyak dilakukan di Australia (Sachlikidis, Jones \& Seymour, 2010). Salah satu kendala dalam kegiatan budidaya pembesaran lobster adalah rendahnya kelangsungan hidup 
benih yang dibudidayakan (Thuy \& Ngoc, 2004). Selain itu, kebutuhan benih yang seragam dan adaptif adalah salah satu permasalahan dalam budidaya pembesaran lobster yang memerlukan solusi pemecahan.

Pembenihan lobster secara komersial belum banyak dilakukan, selain itu teknik pemeliharan larva lobster masih sulit untuk dipahami (Vijayakumaran, Anbarasu \& Kumar, 2010; Jones, 2010). Kegiatan budidaya lobster sedang marak dilakukan oleh beberapa negara ASEAN. Di Vietnam, benih lobster yang tertangkap dipelihara selama 30 - 60 hari terlebih dahulu, sebelum dibudidaya dalam keramba di laut (Chau, Ngoc \& Nhan, 2008). Pada masa pemeliharaan benih inilah, terjadi kematian yang cukup tinggi, yaitu lebih dari setengah bagian, terkadang seluruh benih mengalami kematian (Thuy \& Ngoc, 2004). Menurut Phillips, Melville-Smith \& Cheng (2003), kematian larva pada lobster Panulirus cygnus di alam diperkirakan sangat tinggi (8098\%), yang terjadi pada saat puerulus menetap di dasar perairan serta akibat transportasi benih untuk kegiatan budidaya di darat.

Menurut James, Tong \& Paewai (2002), penggunaan shelter pada lobster meningkatkan kelangsungan hidup, tetapi tidak memberikan pengaruh signifikan terhadap pertumbuhan lobster. Penelitian lain menunjukkan penggunaan shelter jaring pada lobster $P$. cygnus dengan ukuran sekitar $2.26 \pm 0.13$ gram, menghasilkan kelangsungan hidup dan Specific Growth Rate (SGR) masing-masing sebesar $91.7 \pm 3.7 \%$ dan $1.25 \pm 0.03$ (Johnston, Melville-Smith, Hendriks, Maguire \& Phillips, 2006). Dari hasil penelitian ini, penggunaan shelter jaring meminimalkan kontak antar benih lobster, mengurangi stress selama moulting serta memaksimalkan pertumbuhan.

Respon stress merupakan salah satu variabel fisiologi yang sangat penting mempengaruhi tingkat kelangsungan hidup benih lobster. Menurut Jussila, McBride, Jago \& Evans (2001); Verghese, Radhakrishnan \& Padhi (2007); Yildiz \& Benli (2004), Total Hemocycte Count (THC) adalah salah satu parameter yang dapat digunakan sebagai indikator terjadinya stress pada crustacea. Selain THC, jumlah konsentrasi glukosa dalam hemolymph meningkat sebagai respon stress yang diakibatkan oleh handling, emersion, salinitas, penyakit dan polutan (Lorenzon, Giulianini, Martinis \& Ferrero, 2007).

Menurut Chau et al. (2008), informasi mengenai efek penggunaan berbagai tipe atau jenis shelter terhadap pertumbuhan dan kelangsungan hidup benih lobster belum banyak diketahui. Selain hal tersebut, penelitian mengenai efek penggunaan shelter terhadap respon stress benih lobster belum pernah dilakukan, sehingga perlu dilakukan kajian lebih lanjut. Tujuan dari penelitian ini adalah untuk menganalisis dan menentukan jenis shelter yang memberikan respon stress dan produktifitas benih lobster yang paling baik.

\section{BAHAN DAN METODE}

\subsection{Benih Lobster Air Laut}

Benih lobster yang digunakan dalam penelitian ini didapat dari wilayah Lombok Selatan sebanyak 900 ekor. Berat benih lobster yang digunakan dalam peneltian ini \pm 2 gram/ekor. Jenis lobster yang digunakan adalah lobster pasir Panulirus homarus.

\subsection{Shelter}

Shelter yang digunakan pada penelitian ini terdiri dari 3 (tiga) jenis shelter, yaitu shelter dari lubang angin, modifikasi jaring dan pipa paralon (Gambar 1). Volume dari ketiga jenis shelter yang digunakan adalah sama yaitu $8000 \mathrm{~cm}^{3}$.

\subsection{Kolam Penelitian}

Pada penelitian ini digunakan 10 bak kolam. 8 (delapan) buah kolam digunakan untuk perlakuan kemudian 2 (dua) kolam lainnya masing-masing digunakan sebagai tampungan effluen dan tampungan hasil filter. 9 (sembilan) bak kolam percobaan terbuat dari plastik, masing-masing berdimensi $1,2 \times 0,95 \times 1 \mathrm{~m}$ dan 1 (satu) bak kolam fiber bentuk lingkaran dengan diameter 1,5 $\mathrm{m}$ dan tinggi $0,75 \mathrm{~m}$. Pada penelitian ini, digunakan sistem resirkulasi (Gambar 2).

\subsection{Kegiatan Penelitian}

Padat tebar benih lobster dalam penelitian ini adalah 95 ekor/ $\mathrm{m}^{2}$. Selama penelitian, pemberian pakan ikan teri sebesar $10 \%$ juga dilakukan satu kali dalam sehari (Johnston et al., 2006). Pemeliharaan benih selama penelitian dilakukan selama 70 hari. 

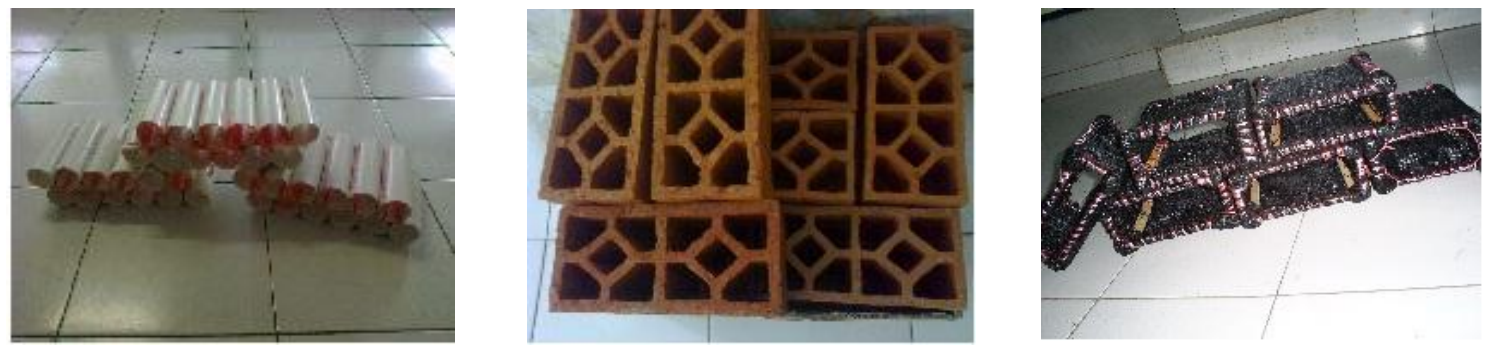

Gambar 1. Beberapa jenis shelter yang digunakan dalam perlakuan: modifikasi paralon (a), lubang angin (b), dan jaring (c).

Figure 1. Severaltypes ofsheltersused in thetreatment. Paralon modified (a), vent (b), and net (c).

Sumber: Dokumentasi pribadi
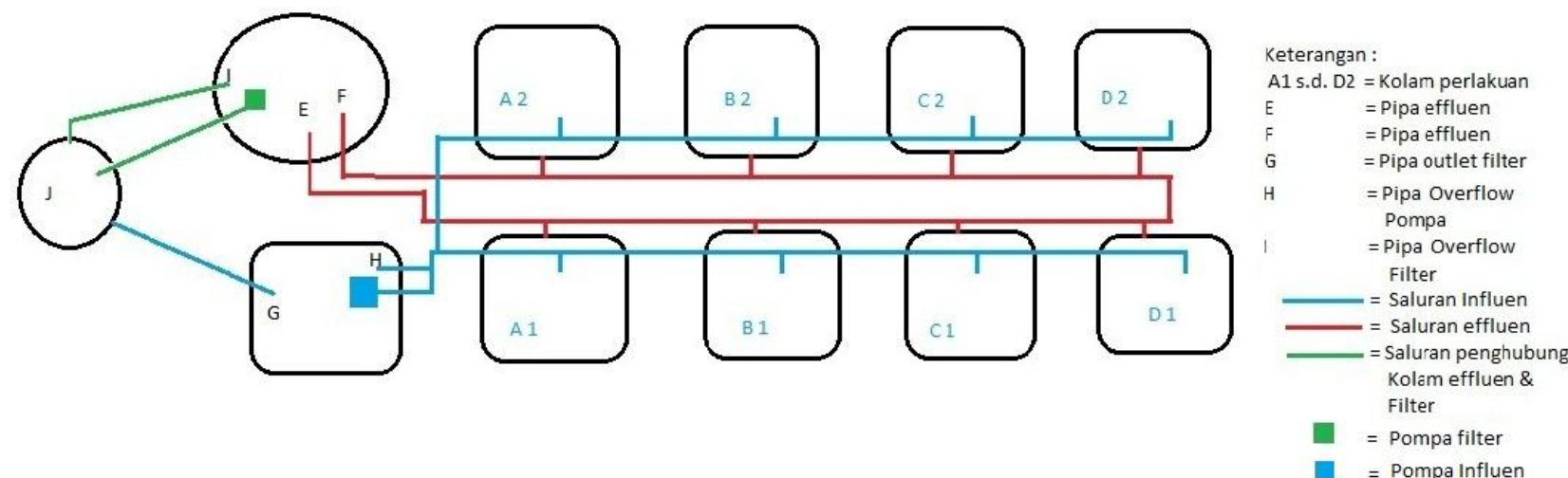

Gambar 2. Sistem resirkulasi pada kolam penelitian

Figure 2. Pool recirculation system on research Sumber: Desain pribadi

Pada penelitian ini digunakan Rancangan Acak Lengkap (RAL), dengan 4 perlakuan dan 2 ulangan. Jenis perlakuan adalah menggunakan shelter dari jaring (A), pipa paralon (B), lubang angin (C) dan tanpa shelter sebagai kontrol (K).

Pengamatan parameter Glukosa dan Total Hemocycte Count (THC) dilakukan pada 0, 24 jam, 3 hari, 7 hari, kemudian setiap 7 hari, sampai akhir penelitian. Analisa glukosa mengacu pada metode Wedemeyer \&Yasutake (1977), sedangkan THC mengacu pada Blaxhall \& Daishley (1973).

Data yang diperoleh dianalisis secara statistik menggunakan analisis ragam (ANOVA) dengan uji F pada selang kepercayaan $95 \%$ menggunakan Software statistik Minitab 16. Apabila berpengaruh nyata, dilakukan uji lanjut menggunakan metode Tukey, untuk melihat perbedaan antar perlakuan yang diuji.

\section{HASIL DAN PEMBAHASAN}

\subsection{Respon THC Hemolymph Lobster pada Berbagai Macam Shelter}

Stres menggambarkan kondisi terganggunya homeostasi hingga berada diluar batas normal serta proses-proses pemulihan untuk diperbaiki. Stres berpengaruh pada sistem kekebalan ikan melalui jalur metabolik (Hastuti, Mokoginta, Dana \& Sutardi, 2004; Leland, Butchera, Broadhursta, Patersonc \& Mayer, 2013; Yeh, Li, Tsui, Lin \& Chen, 2010). Hemosit memainkan peranan penting dalam sistem imun crustacea. Hemosit berperan dalam fagositosis, enkapsulasi, degranulasi dan agregasinodular terhadap patogen atau partikel asing. Respon THC pada berbagai shelter selama penelitian dapat dilihat pada Gambar 3 .

Tampak pada Gambar 3, respon THC lobster pada berbagai macam shelter cenderung fluktuatif. 
Secara keseluruhan konsentrasi THC berada pada kisaran $81,50 \pm 16,26-914,87 \pm 68,76 \times 10^{4} \mathrm{sel} / \mathrm{ml}$. Pada awal penelitian (hari ke-0), konsentrasi THC mempunyai kecenderungan lebih tinggi $\left(870,00 \pm 73,65 \times 10^{4} \mathrm{sel} / \mathrm{ml}\right)$. Hal ini disebabkan, benih lobster mengalami stress dan belum beradaptasi akibat handling awal pemasukan dari kolam aklimatisasi ke kolam perlakuan. Menurut Verghese et al. (2007), perubahan kondisi lingkungan yang baru dapat menyebabkan terjadinya stress terhadap lobster Panulirus homarus, sehingga akan mempengaruhi respon imun yang ditandai dengan perubahan jumlah konsentrasi THC, aktifitas phenoloxidase dan aktifitas fagositosis. Menurut Leland et al. (2013), peningkatan jumlah THC dalam jangka pendek pada awal penelitian, mengindikasikan adanya aktifitas kardiovaskular yang dikombinasikan dengan stress akibat handling dan respon terhadap perubahan lingkungan yang terjadi.

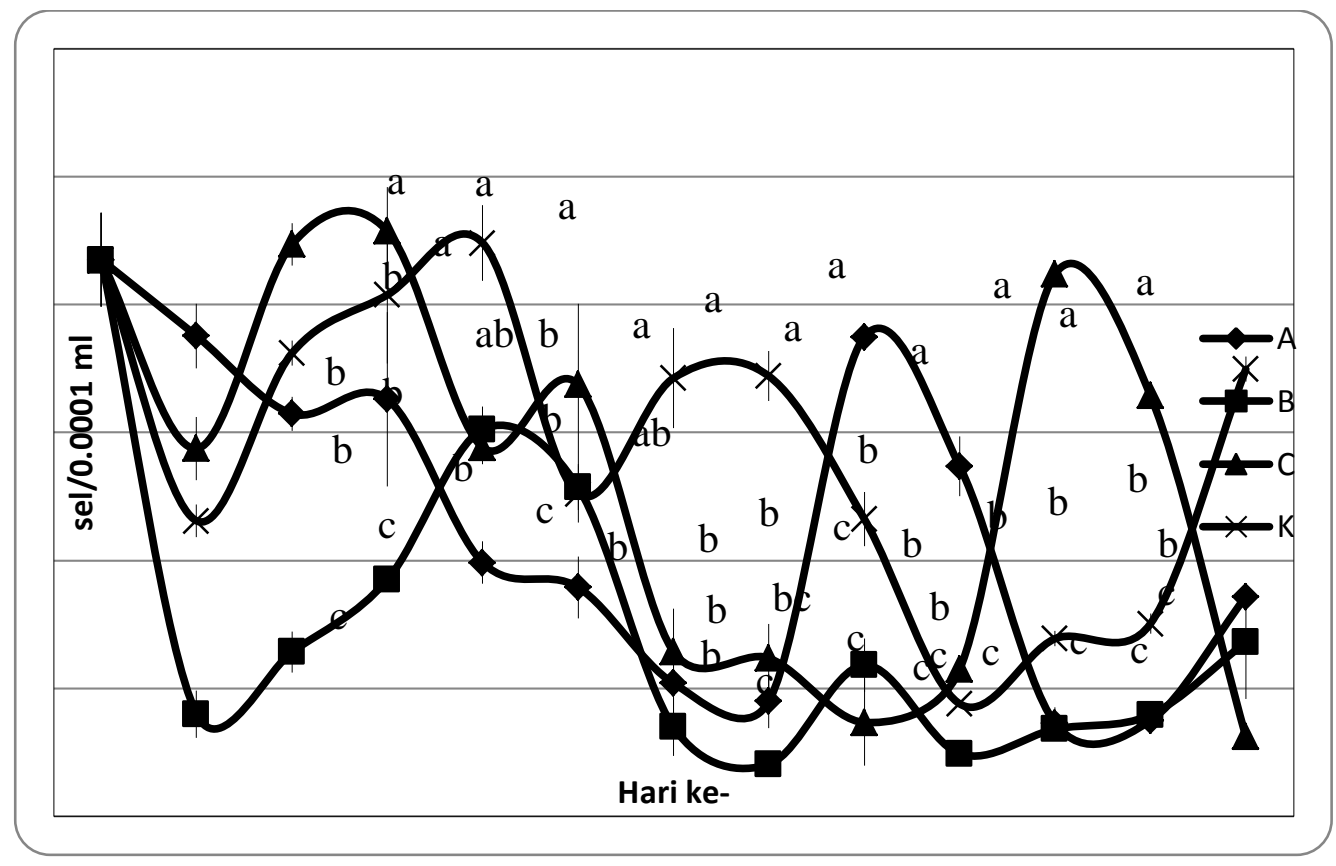

Gambar 3. Respon THC lobster pada berbagai macam shelter selama penelitian. Huruf kecil yang berbeda dalam grafik menunjukkan beda nyata $(\mathrm{p}<0,05)$

Figure 3. Lobster THC response on various shelters during the study. Different lowe rcase in the graph indicate significant difference $(p<0.05)$.

Sumber: Hasil pengolahan data

Pada hari ke-1, konsentrasi THC cenderung mengalami penurunan, kemudian meningkat kembali sampai dengan hari ke-7. Hal ini, menunjukkan proses adaptasi benih lobster terhadap lingkungan yang baru, masih berjalan. Menurut penelitian Fotedar, Evans \& Jones (2006), konsentrasi THC pada lobster Panulirus cygnus mengalami kenaikan pada saat penangkapan dan transport akibat stress, kemudian akan mengalami penurunan setelah 16-48 jam di kolam pemeliharaan. Tampak pada Gambar 3, kecenderungan konsentrasi THC sampai hari ke-7, pada shelter lubang angin lebih tinggi 914,87 \pm $68,76 \times 10^{4} \mathrm{sel} / \mathrm{ml}$ ) dibandingkan kontrol dan shelter lainnya. Konsentrasi THC terendah terdapat pada perlakuan mengunakan shelter paralon $\left(377 \pm 7,07 \times 10^{4} \mathrm{sel} / \mathrm{ml}\right)$. Hal tersebut menunjukkan, jenis shelter paralon mempunyai kemampuan yang paling baik dalam menekan tingkat stress selama pemeliharaan periode 7 harian. Dari hasil analisis statistik, perlakuan menggunakan shelter paralon berbeda nyata $(\mathrm{p}<0,05)$ dengan perlakuan shelter jaring, lubang angin dan kontrol (hari ke-1 dan 3). Demikian juga hari ke-7, perlakuan shelter paralon berbeda nyata $(\mathrm{p}<0,05)$ dengan shelter lubang angin dan kontrol, tetapi tidak berbeda nyata $(p>0,05)$ dengan shelter jaring. 
Konsentrasi THC pada semua perlakuan cenderung mengalami penurunan pada hari ke-14, kecuali pada kontrol mengalami kenaikan dan lebih tinggi dari perlakuan lainnya. Pada hari ke-21 sampai hari ke-70, konsentrasi THC pada perlakuan shelter paralon mempunyai kecenderungan lebih rendah dan stabil apabila dibandingkan dengan perlakuan lainnya. Hal ini menunjukkan, shelter paralon memiliki kemampuan yang lebih baik untuk menekan stress sehingga THC lobster yang dihasilkan lebih rendah dan stabil apabila dibandingkan perlakuan lainnya.

\subsection{Respon Glukosa Hemolymph Lobster pada Berbagai Macam Shelter}

Pada kondisi stres terjadi realokasi energimetabolik aktivitas investasi (seperti pertumbuhandan reproduksi) menjadi aktivitas untuk memperbaiki homeostasi, seperti respirasi, pergerakan, regulasi hidromineral dan perbaikan jaringan. Kebutuhan energi untuk memperbaiki homeostasi selama stres dipenuhi oleh proses glikogenolisis dan glukoneogenesis yang menghasilkan glukosa (Hastuti et al., 2004; Ocampo, Patino \& Ramirez, 2003). Respon Glukosa lobster pada berbagai shelter selama penelitian dapat dilihat pada Gambar 4.

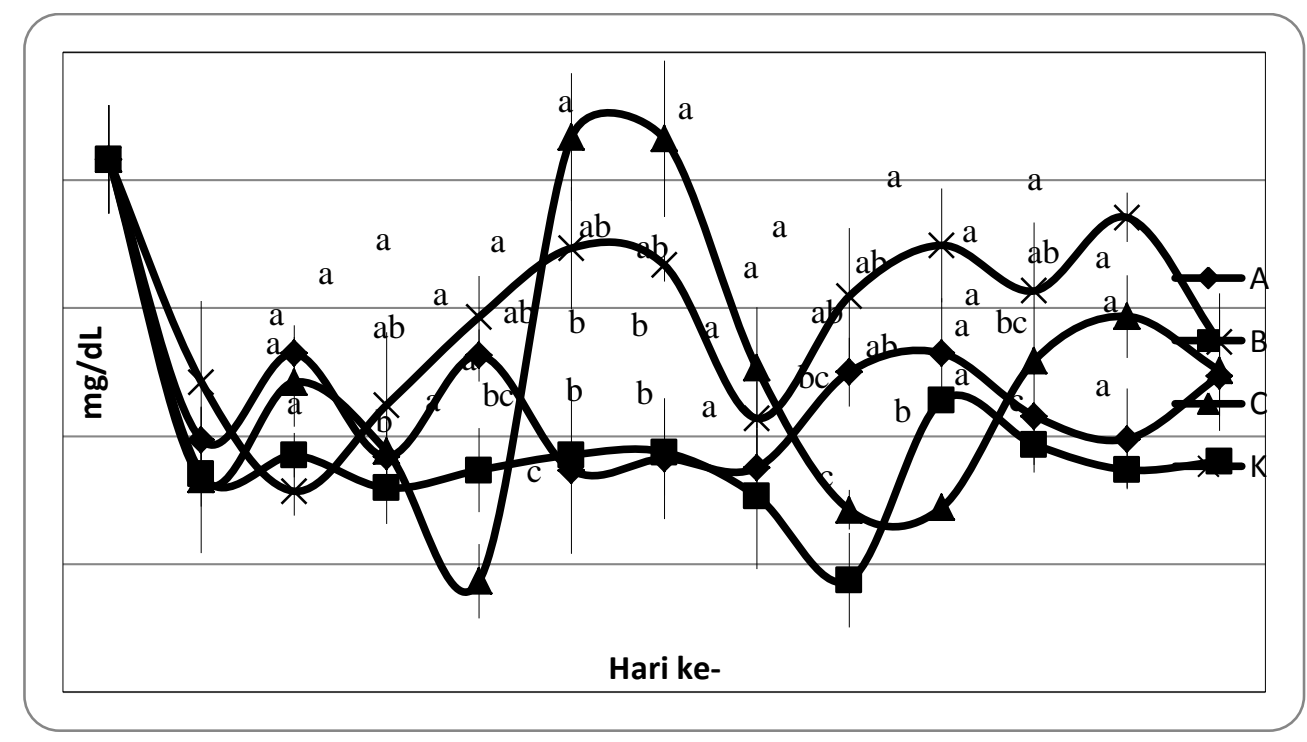

Gambar 4. Respon glukosa lobster pada berbagai macam shelter selama penelitian. Huruf kecil yang berbeda dalam grafik menunjukkan beda nyata $(\mathrm{p}<0,05)$.

Figure 4. Lobster glucose response on various shelters throughout the study. Different lower case in the graph indicate significant difference $(p<0.05)$.

Sumber: Hasil pengolahan data

Tampak pada Gambar 4, respon glukosa lobster pada berbagai macam shelter cenderung fluktuatif. Secara keseluruhan konsentrasi glukosa berada pada kisaran $7,65 \pm 2,85-21,67 \pm 3,05 \mathrm{mg} /$ dl. Pada awal penelitian (hari ke-0), konsentrasi glukosa mempunyai kecenderungan lebih tinggi $(20,80 \pm 2,123 \mathrm{mg} / \mathrm{dl})$ apabila dibandingkan dengan kondisi glukosa selama penelitian. Hal ini disebabkan benih lobster mengalami stress pada saat handling awal untuk ditebar pada kolam pemeliharaan. Stress yang terjadi dikarenakan adanya perubahan ke kondisi lingkungan yang baru (perpindahan kolam, air, dan suhu). Menurut Hastuti, Supriyono, Mokoginta \& Subandiyono (2003) stress menyebabkan peningkatan kadar glukosa darah (hiperglisemia), dimana mekanisme terjadinya adalah sebagai berikut: (1) pemecahan glikogen hati dan otot melalui jalur glikogenolisis yang menghasilkan glukosa dan merupakan efek metabolisme katekolamin; (2) pemecahan protein dan lipid melalui jalur gluko-neogenesis yang merupakan efek metabolisme kortisol; (3) inaktifasi insulin sebagai efek metabolisme 
hormon stres sehingga menutup penggunaan glukosa oleh sel.

Pada hari ke-1 (24 jam), konsentrasi glukosa pada semua perlakuan telah mengalami penurunan pada kisaran $8,29 \pm 2,85-12,10 \pm 3,17 \mathrm{mg} / \mathrm{dL}$. Hal ini sesuai dengan penelitian yang dilakukan Lorenzon et al. (2007), dimana pemberian perlakuan stress pada lobster Homarus americanus, setelah 24 jam pengamatan, kadar glukosa hemolymph mengalami penurunan yang signifikan dari 0.85 $\mathrm{mmol} / \mathrm{L}$ menjadi $0,4 \mathrm{mmol} / \mathrm{L}$. Menurut Hastuti et al. (2003), penurunan kadar glukosa ini, disebabkan lobster telah beradaptasi dengan lingkungan yang baru dimana proses samping katabolisme protein berupa asam amino akan meningkat dalam darah. Asam amino ini akan mengaktivasi insulin kembali sehingga mampu melakukan transport glukosa, yang menyebabkan konsentrasi glukosa dalam darah akan menurun kembali.

Pada kurun waktu penelitian hari ke- 1 sampai hari ke-14, konsentrasi glukosa pada semua perlakuan relatif stabil yaitu berkisar antara $7,97 \pm 1,40-14,65 \pm 2,86 \mathrm{mg} / \mathrm{dL}$. Pada hari ke-21 sampai hari ke 28, terjadi peningkatan kadar glukosa pada perlakuan shelter lubang angin dan kontrol. Hasil analisis statistik pada hari ke-21 dan 28, menunjukkan perlakuan shelter paralon berbeda nyata $(\mathrm{p}<0,05)$ dengan shelter lubang angin, tetapi tidak berbeda nyata $(\mathrm{p}>0,05)$ dengan shelter jaring dan kontrol. Tren peningkatan kadar glukosa ini juga diikuti oleh perlakuan lainnya pada hari ke-42 sampai akhir penelitian (hari ke70). Peningkatan kadar glukosa ini merupakan indikator terjadinya stress pada benih lobster yang diperlihara. Stress yang terjadi kemungkinan disebabkan benih lobster terkena penyakit Milky hemolymph Disease. Menurut Hoang, Sang, Kien \& Bich (2008), Milky hemolymph Disease ini mucul sekitar akhir tahun 2006 di Vietnam. Penyebab penyakit ini adalah Rickettsail-like bacteria (RLB), yang kemungkinan berasal dari pakan segar (teri) yang diberikan. Beberapa ciri dari penyakit ini adalah lobster menjadi lemah, nafsu makan menurun, munculnya warna keputihan pada otot perut, dan lobster mengalami kematian. Dari serangkaian pengamatan yang dilakukan warna hemolymph yang dihasilkan oleh lobster yang terinfeksi menjadi berwarna putih susu keruh, berbeda dengan hemolymph lobster yang sehat (bening). Gambar 5 berikut menunjukkan gejala lobster yang terinfeksi Milky Hemolymph Disease dan lobster sehat.

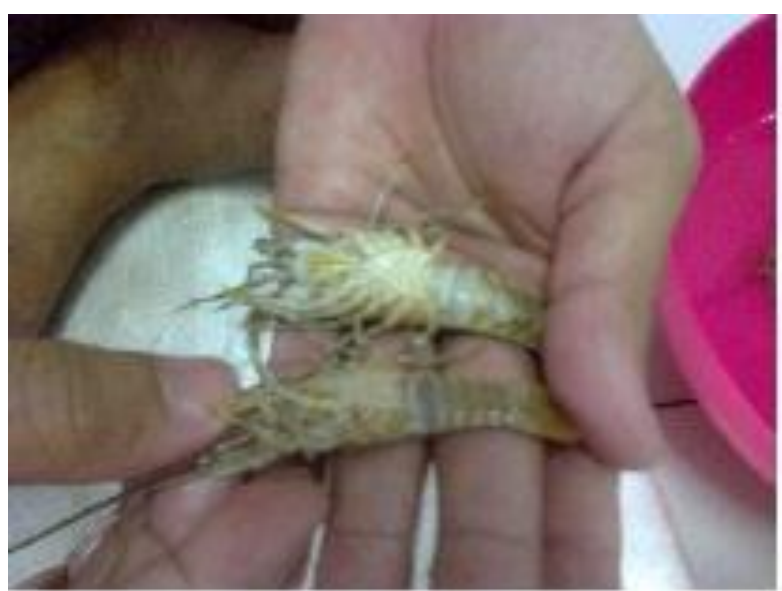

Gambar 5. Lobster sakit (atas) dan lobster sehat (bawah).

Figure 5. Sick lobster (up) and healthy lobster (bottom) Sumber: Koleksi pribadi

Meskipun selama penelitian, lobster terindikasi penyakit Milky Hemolymph Disease, namun tampak jelas respon stress yang dihasilkan oleh beberapa perlakuan tampak berbeda. Tampak pada Gambar 4, konsentrasi glukosa selama penelitian pada perlakuan shelter paralon dan jaring, relatif lebih rendah dan stabil apabila dibandingkan perlakuan shelter lubang angin dan kontrol yang cenderung lebih tinggi dan fluktuatif. Hal tersebut menunjukkan pemberian shelter jenis paralon dan jaring, mempunyai kemampuan menekan stress, apabila dibandingkan shelter lubang angin dan kontrol.

Respon stress yang dihasilkan pada tiap shelter berkaitan dengan respon tingkah laku lobster terhadap objek shelter. Menurut Rossong, Quijon, Williams \& Snelgrove (2011), lobster juvenile lebih menyukai shelter yang terbuat dari bahan yang mempunyai warna yang lebih gelap/tidak transparan dan mempunyai banyak celah. Selain itu, lobster juvenil lebih banyak menghabiskan waktu untuk berlindung di dalam shelter dibanding lobster dewasa. Menurut Kari, Spanier \& Grasso (2007), lobster S. Elisabethae dan S. Aequinoctialis lebih menyukai bentuk shelter yang menyerupai lubang gua dalam batu atau karang seperti di habitat alaminya, dengan 2 jalan masuk pada ujung shelter yang terbuka. Pada penelitian lain secara laboratorium, lobster lebih menyukai substrat buatan yang berasal dari bahan plastik yang mempunyai permukaan lebih kasar. 
Berdasarkan hal tersebut, shelter paralon memberikan respon stress yang paling rendah dan stabil karena shelter paralon mempunyai bentuk menyerupai lubang dengan 2 sisi permukaan yang terbuka pada ujung shelter. Selain itu bahan dari pipa paralon adalah Polyvinyl Chloride (PVC) yang merupakan polimer termoplastik.

\subsection{Kelangsungan Hidup}

Secara keseluruhan, tingkat kelangsungan hidup benih lobster pada akhir penelitian, dapat dilihat pada Gambar 6 berikut ini.

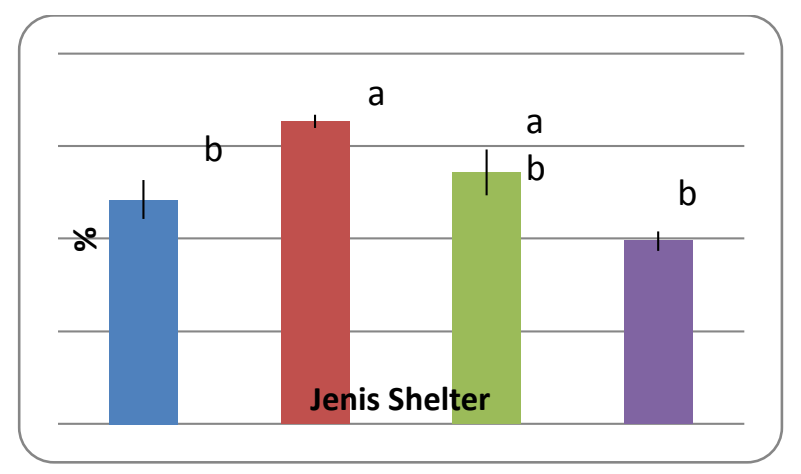

Gambar 6. Kelangsungan hidup lobster pada akhir penelitian. Huruf kecil yang berbeda dalam grafik menunjukkan beda nyata $(\mathrm{p}<0,05)$.

Figure 6. Survival rate oflobstersat theend of the study. Different lower case in the graph indicate significant difference $(p<0.05)$.

Sumber: Hasil pengolahan data

Tampak pada Gambar 6, kelangsungan hidup paling tinggi terdapat pada penggunaan shelter paralon sebesar $65 \%$, sedangkan paling rendah terdapat pada kontrol (tanpa shelter) sebesar $39 \%$. Tingginya tingkat kelangsungan hidup lobster pada penggunaan shelter paralon menunjukkan lebih rendahnya tingkat stress benih lobster yang dipelihara. Menurut Fotedar et al. (2006) dan Verghese et al. (2007), stress dapat menyebabkan turunnya kemampuan imunologi terhadap penyakit, gangguan pertumbuhan, kinerja reproduksi yang buruk, dan kelangsungan hidup lebih rendah. Hasil analisis statistik menunjukkan, tingkat kelangsungan hidup pada shelter paralon berbeda nyata $(p<0,05)$ dengan shelter jaring dan kontrol, tetapi tidak berbeda nyata $(p>0,05)$ dengan shelter lubang angin.

Dari kajian THC dan kadar glukosa, shelter paralon terbukti mampu menekan stress dengan kondisi yang lebih baik jika dibandingkan dari perlakuan lainnya. Pada kontrol, tingkat kelangsungan hidup yang dihasilkan paling rendah. Hal ini disebabkan selain karena tingkat stress yang lebih tinggi, perlakuan tanpa shelter memungkinkan kontak antar lobster lebih tinggi sehingga akan menurunkan tingkat kelangsungan hidup. Hal ini sesuai dengan penelitian yang dilakukan oleh Lorenzon et al. (2007), bahwa penggunaan shelter meminimalkan kontak antar benih lobster, mengurangi stress selama moulting, memaksimalkan pertumbuhan dan menghasilkan tingkat kelangsungan hidup yang lebih baik.

\section{KESIMPULAN DAN SARAN}

\section{Kesimpulan}

Penggunaan shelter pada pendederan lobster Panulirus homarus menghasilkan tingkat stress yang lebih rendah dibandingkan kontrol, ditinjau dari respon THC dan glukosa hemolymph lobster selama penelitian. Tingkat stress yang lebih rendah menyebabkan tingkat kelangsungan hidup yang dihasilkan lebih tinggi. Shelter paralon merupakan shelter yang terbaik, karena mampu menekan tingkat stress dan menghasilkan kelangsungan hidup yang lebih baik dibanding perlakuan lainnya.

\section{Saran}

Perlunya dilakukan pengkajian respon stress terhadap beberapa variabel fisiologi lainnya seperti hormon, produk metabolisme, dan tingkah laku. Pengkajian respon stress terhadap variabel fisiologi lainnya, dimaksudkan untuk mengetahui sejauh mana interaksi yang ditimbulkan antar variabel selama berlangsungnya stress pada lobster.

\section{DAFTAR PUSTAKA}

Blaxhall, P.C., \& Daishley, K.W. (1973). Routine haematological methods for usewith fish blood. Journal of Fish Biology, 5, 577-581.

Chau, N.M., Ngoc, NTB, \& Nhan, L.T. (2008). Effect of different types of shelter on growth and survival of Panulirus ornatus juveniles. Di dalam: Williams KC, editor. Spiny Lobster Aquaculture in the Asia-Pacific Region; 2008 Des 9-10; Nha Trang, Vietnam. Canberra (AU): Australian Centre for International Agricultural Research, 85-88. 
Drengstig, A., \& Bergheim A. (2013). Commercial land-based farming of European lobster (Homarus gammarus L.) in recirculating aquaculture system (RAS) using a single cage approach. Journal of Aquacultural Engineering, 53, 14- 18.

Fotedar, S., Evans, L., \& Jones B. (2006). Effect of holding duration on the immune system of western rock lobster, Panulirus cygnus. Journal of Comparative Biochemistry and Physiology, Part A 143, 479-487.

Hastuti, S., Mokoginta, I., Dana, D., \& Sutardi, T. (2004). Resistensi terhadap stres dan respons imunitas ikan gurami (Osphronemus Gouramy, Lac.) yang diberi pakan mengandung kromiumragi. Jurnal Ilmu-Ilmu Perairan dan Perikanan Indonesia, 11(1), 15-21.

Hastuti, S., Supriyono, E., Mokoginta, I., \& Subandiyono. (2003). Respon glukosa darah ikan gurami (Osphronemus gouramy, LAC.) terhadap stres perubahan suhu lingkungan. Jurnal Akuakultur Indonesia, 2(2), 73-77.

Hoang, D.H., Sang, H.M., Kien, N.T., \& Bich, N.T.K. (2008). Culture of Panulirus ornatus lobster fed fish by-catch or co-cultured Perna viridismussel in sea cages in Vietnam. Di dalam: Williams, K.C., editor. Spiny Lobster Aquaculture in the Asia-Pacific Region; 2008 Des 9-10; Nha Trang, Vietnam. Canberra (AU): Australian Centre for International Agricultural Research, 118-125.

James,P.J., Tong, L., \& Paewai, M. (2002). Effect of stocking density and shelter on growth and mortality of early juvenile Jasus edwardsii held in captivity. Journal of Marine and Freshwater Research, 52(8), 1413-1417.

Johnston, D., Melville-Smith, R., Hendriks, B., Maguire, G.B., \& Phillips, B. (2006). Stocking density and shelter type for the optimal growth and survival of Western Rock lobster Panulirus cygnus (George). Journal of Aquaculture. 260, 114-127.

Jones, C.M. (2010). Tropical spiny lobster aquaculture development in Vietnam, Indonesia and Australia. Journal of Marine Biological Assay India, 52(2).

Jussila, J., McBride, S., Jago, J., \& Evans, L.H. (2001). Hemolymph clotting time as an indicator of stress in Western Rock lobster (Panulirus cygnus George). Journal of aquaculture, 199, 185-193.

Kari, L.L., Spanier, E., \& Grasso, F. (2007). Behavior and sensory biology of slipper lobsters. Di dalam: The Biology and Fisheries of the Slipper Lobster. Crustacean issues 17. Boca Raton (US): CRC Press, 133-181.

Leland, J.C., Butchera, P.A., Broadhursta, M.K., Patersonc BD, \& Mayer DG. (2013). Damage and physiological stress to juvenile eastern rock lobster (Sagmariasus verreauxi) discarded after trapping and hand collection. Journal of Fisheries Research, 137, 63-70.

Lorenzon, S., Giulianini, P.G., Martinis, M., \& Ferrero, E.A. (2007). Stress effect of different temperatures and air exposure during transport on physiological profiles in the American Lobster Homarus americanus. Journal of Comparative Biochemistry and Physiology, Part A 147, 94-102.

Ocampo, L., Patino, D., \& Ramirez, C. (2003). Effect of temperature on hemolymph lactate and glucose concentrations in spiny lobster Panulirus interruptus during progressive hypoxia.Journal of Experimental Marine Biology and Ecology, 296, 71- 77.

Phillips, B.F., Melville-Smith, R., \& Cheng, Y.W. (2003). Estimating the effects of removing Panulirus cygnus pueruli on the fishery stock. Journal of Fishery Research, 65, 89-101.

Rossong, M.A., Quijon, P.A., Williams, P.J., \& Snelgrove, P.V.R. (2011). Foraging and shelter behavior of juvenile American lobster (Homarus americanus): the influence of a nonindigenous crab. Journal of Experimental Marine Biology and Ecology, 403, 75-80.

Sachlikidis, N.G., Jones, C.M., \& Seymour, J.E. (2010). The effect of temperature on the incubation of eggs of the tropical rock lobster Panulirus ornatus. Journal of Aquaculture, 30, 79-83.

Thuy, N.T.B., \& Ngoc, N.T.B. (2004). Current status and exploitation of wild spiny lobsters in Vietnamese waters. Di dalam: Williams KC, editor. Spiny Lobster Ecology and Exploitation in The South China Sea Region.; 2004 Jully ; Nha Trang, Vietnam. Canberra (AU): Australian Centre for International Agricultural Research. hlm 13-16. Proceedings No. 120, 1316. Australian Centre for International Agricultural Research: Canberra.

Verghese, B., Radhakrishnan, E.V., \& Padhi, A. (2007). Effect of environmental parameters on immune response of the Indian spiny lobster, Panulirus homarus (Linnaeus, 1758). Journal of Fish \& Shellfish Immunology 23, 928-936.

Vijayakumaran, M., Anbarasu, M., \& Kumar, T.S. (2010). Moulting and growth in communal and individual rearing of the spiny lobster, Panulirus homarus. Journal of Marine Biology Assaay India 52(2), 274 -281.

Wedemeyer, G.A., \& Yasutake, W.T. (1977). Clinical Methods for the Assessment of the Effects of Environmental Stress on Fish Health. Volume ke-89. Washington DC (US). Department of the Interior Fish and Wildlife Service. 
Yeh, S.T., Li, C.C., Tsui, W.C., Lin, Y.C., \& Chen, J.C. (2010). The protective immunity of white shrimp Litopenaeus vannamei that had been immersed in the hot-water extract of Gracilaria tenuistipitata and subjected to combined stresses of Vibrio alginolyticus injection and temperature change. Journal of Fish \& Shellfish Immunology, 29, 271-278.

Yildiz, H.Y., \& Benli, ACK. (2004). Nitrite toxicity to crayfish, Astacus leptodactylus, the effects of sublethal nitrite exposure on hemolymph nitrite, total hemocytecounts, and hemolymph glucose. Journal of Ecotoxicology and Environmental Safety, 59, 370-375. 